\title{
First admissions to psychiatric hospitals in south-east England in 1976 among immigrants from Ireland
}

\author{
GEOFFREY DEAN, HELEN DOWNING, EMER SHELLEY
}

\begin{abstract}
Irish male immigrants had twice and female immigrants 1.7 times the expected number of first admissions to psychiatric hospitals in south-east England in 1976 when the expected number was based on the age- and sexstandardised rates of first admission of the population born in the United Kingdom living in the region. Admissions for alcoholism and alcoholic psychosis were five times higher in men and four times higher in women, and for schizophrenia 2.4 times as high in both sexes, as expected from these rates. When the expected number of first admissions was based on the age- and sexstandardised rates among Irish people living in Ireland the immigrants had fewer admissions than expected. Among migrants from Northern Ireland the number of first admissions was significantly greater than expected. Admissions for alcoholism and alcoholic psychosis in men and women combined were seven times the expected number based on the UK rates. There was no significant difference in the proportion of single people between the Irish immigrants and people born in the UK.

Marital state, socioeconomic group, and occupation may partly account for the high number of admissions for alcoholism and schizophrenia among Irish people living in south-east England.
\end{abstract}

\section{Introduction}

We report here a study of first admissions to psychiatric hospitals among Irish immigrants in south-east England. This was part of a larger comparative study of first admissions to psychiatric hospitals during 1976 among New Commonwealth and European immigrants and people born in the United Kingdom living in south-east England (G Dean et al, paper in preparation).

We examined the admission patterns of Irish immigrants in

Medico-Social Research Board, Dublin 2

GEOFFREY DEAN, MD, FRCP, director

HELEN DOWNING, BSOCSC, DIPSTATS, research assistant

EMER SHELLEY, MB, MRCPI, research assistant detail by age, sex, and diagnostic category. We compared admission rates of Irish immigrants with those of the population $\vec{\infty}$ born in the $\mathrm{UK}$ and those of the Irish population living in Ireland. We also compared first admissions to psychiatric 을 hospitals among people who had migrated from Northern $\sigma$ Ireland with admissions of those born in any part of the UK and living in south-east England.

\section{Method}

The study was based on data from the English census county reports for $1971,{ }^{1}$ Department of Health and Social Security inpatient $\bar{\partial}$ statistics for 1976 (unpublished data), and the Activities of Irish Psychiatric Hospitals and Units 1975 and 1976. ${ }^{2}$ The 1971 census of $\mathbb{Q}$ population was used to calculate the populations at risk by age group. In 1971 there were 146005 male and 173405 female im- 음 migrants from the Republic of Ireland and Ireland part not stated 3 resident in the area under study in south-east England. Between 1971 and 1976 the Irish-born population in England fell slightly because of diminished emigration from Ireland and because the number who returned to Ireland increased, as was shown by the Irish 1979 census. $^{3}$

We analysed first admissions to psychiatric hospitals and units in the four Thames regional health authorities and the London board of governors hospitals. An expected number of admissions was calculated for Irish immigrants living in south-east England based on the admissions in each age group, sex, and diagnostic category of $\frac{\text { a }}{2}$ people born in the UK. Expected admission figures were also cal- $N$ culated by using the age- and sex-specific first admissions to psy- $\sigma$ chiatric hospitals in Ireland. A similar theoretical number of expected $\frac{D}{0}$ first admissions was derived for men and women from Northern Ireland based on the admission of those born in any part of the UK N living in south-east England. The $\chi^{2}$ test was used to determine the N significance of differences between the expected and actual numbers of admissions.

\section{Results}

In 1976 among people born in the UK and living in south-east England women had a higher overall first admission rate than men, and the highest first admission rates for both sexes occurred in those $\mathbb{Q}$ aged 20-34 years. The diagnostic categories with the highest admission rates were personality and behaviour disorders and psychoneuroses for men born in the UK and psychoneuroses and senile and $\frac{0}{0}$ presenile psychoses for women. Birthplace was recorded for over $91 \%$ of all first admissions in 1976. 
Table I gives the rates of first admission for male and female immigrants from Ireland (Republic of Ireland and Ireland part not stated combined) to psychiatric hospitals in south-east England by age, sex, and diagnostic category. The highest admission rates among male immigrants occurred in those aged 35-54 years and among female immigrants in those aged 55 years and over. The diagnostic category with the highest admission rate was alcoholic psychosis and alcoholism for men and psychoneuroses for women.

Table II shows the actual number of first admissions of Irish immigrants together with the age- and sex-standardised expected number of such admissions for each sex and diagnostic category, based on the rates of first admission among people born in the UK living in south-east England. The actual number of admissions for all diagnoses was more than twice the expected number among men and 1.7 times the expected number among women. Among Irish male immigrants alcoholic psychosis (21 admissions) and alcoholism (94) combined (115) was the category with the highest number of admissions, which was 5.3 times the expected number. The number of admissions for schizophrenia was 2.4 times the expected number, and the numbers of admissions for other psychoses, personality disorders, and "all other conditions" were significantly higher than expected $(p<0.05)$.

Among Irish female immigrants psychoneuroses was the category with the highest number of admissions, which was significantly more than expected. Schizophrenia was the second largest group, the number of admissions being $2 \cdot 4$ times the expected number. Alcoholic psychosis (four admissions) and alcoholism (40) combined (44) was the third largest group, being four times the expected number. Admissions for personality and behaviour disorders and for all other conditions combined were also significantly higher than expected.

The high number of admissions for alcoholic psychosis and alcoholism among the Irish immigrants of both sexes contrasts with the small number among immigrants from Germany (two admissions), Italy (none), and Poland (six). The expected number based on the

TABLE I-Age- and sex-standardised rates of first admission to psychiatric hospitals (1976)/100 000 population among Irish immigrants from Irish republic and Ireland part not stated living in south-east England (numbers in parentheses are actual numbers of admissions)

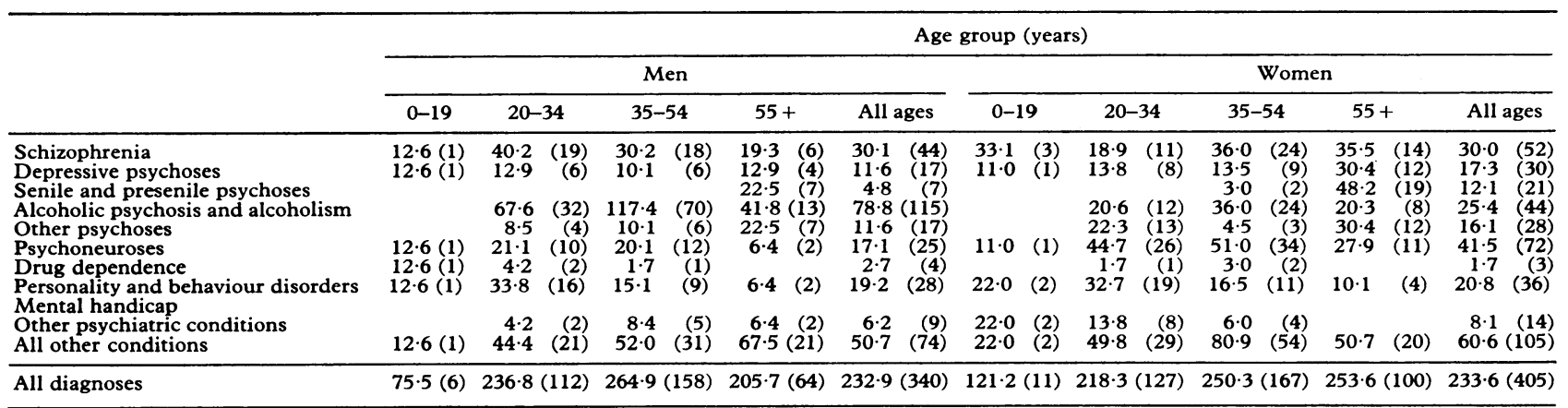

TABLE II-First admissions of Irish immigrants from Irish republic and Ireland part not stated to psychiatric hospitals in south-east England in 1976: numbers expected from age-specific rates for people born in the UK and actual numbers

\begin{tabular}{|c|c|c|c|c|c|c|}
\hline \multirow[b]{2}{*}{ Diagnostic category } & \multicolumn{3}{|c|}{ Men } & \multicolumn{3}{|c|}{ Women } \\
\hline & $\begin{array}{l}\text { Expected } \\
\text { No }\end{array}$ & $\begin{array}{c}\text { Actual } \\
\text { No }\end{array}$ & $x^{2}$ & $\begin{array}{c}\text { Expected } \\
\text { No }\end{array}$ & $\begin{array}{l}\text { Actual } \\
\text { No }\end{array}$ & $x^{2}$ \\
\hline \multirow{5}{*}{$\begin{array}{l}\text { Schizophrenia } \\
\text { Depressive psychoses } \\
\text { Senile and presenile } \\
\text { psychoses } \\
\text { Alcoholic psychosis and } \\
\text { alcoholism } \\
\text { Other psychoses } \\
\text { Psychoneuroses } \\
\text { Drug dependence } \\
\text { Personality and } \\
\text { behaviour disorders } \\
\text { Mental handicap } \\
\text { Other psychiatric } \\
\text { conditions } \\
\text { All other conditions }\end{array}$} & $\begin{array}{l}18 \cdot 7 \\
12.5\end{array}$ & $\begin{array}{l}44 \\
17\end{array}$ & $\mathrm{p}<0.01$ & $\begin{array}{l}21 \cdot 7 \\
25 \cdot 0\end{array}$ & $\begin{array}{l}52 \\
30\end{array}$ & $\mathrm{p}<0.01$ \\
\hline & $7 \cdot 6$ & 7 & & $17 \cdot 5$ & 21 & \\
\hline & $\begin{array}{r}21.5 \\
9.7 \\
23.9 \\
4.1\end{array}$ & $\begin{array}{r}115 \\
17 \\
25 \\
4\end{array}$ & $\begin{array}{l}\mathrm{p}<0.01 \\
\mathrm{p}<0.05\end{array}$ & $\begin{array}{r}10 \cdot 4 \\
20 \cdot 6 \\
49 \cdot 1 \\
1 \cdot 7\end{array}$ & $\begin{array}{r}44 \\
28 \\
72 \\
3\end{array}$ & $\begin{array}{l}\mathbf{p}<0.01 \\
.<0.01\end{array}$ \\
\hline & $\begin{array}{r}19.1 \\
0.5\end{array}$ & $\begin{array}{r}28 \\
0\end{array}$ & $\mathrm{p}<0.05$ & $\begin{array}{r}21 \cdot 2 \\
0.7\end{array}$ & 36 & $\mathrm{p}<0.01$ \\
\hline & $\begin{array}{r}6.4 \\
33.8\end{array}$ & $\begin{array}{r}9 \\
74\end{array}$ & $\mathrm{p}<0.01$ & $\begin{array}{l}11 \cdot 3 \\
66 \cdot 2\end{array}$ & $\begin{array}{r}14 \\
105\end{array}$ & $\mathrm{p}<0.01$ \\
\hline All diagnoses & $157 \cdot 8$ & 340 & $\mathrm{p}<0.01$ & $245 \cdot 4$ & 405 & $\overline{p<0.01}$ \\
\hline
\end{tabular}

TABLE III-First admissions of Irish immigrants from Irish republic and Ireland part not stated to psychiatric hospitals in south-east England in 1976: numbers expected from age-specific rates for people born in the Irish republic and actual numbers

\begin{tabular}{|c|c|c|c|c|}
\hline \multirow[b]{2}{*}{ Diagnostic category } & \multicolumn{2}{|c|}{ Men } & \multicolumn{2}{|c|}{ Women } \\
\hline & $\begin{array}{l}\text { Expected } \\
\text { No }\end{array}$ & $\begin{array}{l}\text { Actual } \\
\text { No }\end{array}$ & $\begin{array}{l}\text { Expected } \\
\text { No }\end{array}$ & $\begin{array}{l}\text { Actual } \\
\text { No }\end{array}$ \\
\hline $\begin{array}{l}\text { Schizophrenia } \\
\text { Depressive psychoses }\end{array}$ & $\begin{array}{r}135 \cdot 9 \\
92 \cdot 8\end{array}$ & $\begin{array}{l}44 \\
17\end{array}$ & $\begin{array}{l}113 \cdot 3 \\
188 \cdot 4\end{array}$ & $\begin{array}{l}52 \\
30\end{array}$ \\
\hline $\begin{array}{l}\text { Other psychoses and senile and } \\
\text { presenile psychoses }\end{array}$ & $59 \cdot 8$ & 24 & $135 \cdot 7$ & 49 \\
\hline Alcoholic psychosis and alcoholism & 304.5 & 115 & $79 \cdot 1$ & 44 \\
\hline $\begin{array}{l}\text { Drug dependence } \\
\text { Personality and behaviour disorders, }\end{array}$ & $7 \cdot 0$ & 4 & $4 \cdot 8$ & 3 \\
\hline $\begin{array}{l}\text { psychoneuroses, and other } \\
\text { psychiatric conditions }\end{array}$ & $107 \cdot 1$ & 62 & $167 \cdot 3$ & 122 \\
\hline Mental handicap & 13.5 & 0 & $14 \cdot 9$ & 0 \\
\hline All other conditions & $17 \cdot 3$ & 74 & $15 \cdot 2$ & 105 \\
\hline All diagnoses & 737.9 & 340 & $718 \cdot 7$ & 405 \\
\hline
\end{tabular}

All differences between expected and actual numbers significant $(p<0.01)$ except for drug dependence. rate for people born in the UK for these three countries combined was 14.

Actual numbers of first admissions among male and female immigrants from Ireland living in south-east England were also compared with a theoretical number of expected admissions based on age- and sex-standardised first admission rates for Irish people living in Ireland. Table III shows the results. The classification of mental illness differs slightly between Ireland and the UK, so some of the diagnostic categories are broader than when only admissions in the UK are considered. Both male and female immigrants had a significantly lower number of first admissions in England than would be expected from admission rates in Ireland, and admissions were significantly fewer than expected for all diagnostic categories except drug dependence. There were more admissions for "all other conditions" than would be expected (as "unspecified") based on admission rates in Ireland, but this was due to differences in classification.

Seventy-one men and 69 women from Northern Ireland and Ulster part not stated were admitted to psychiatric hospitals in south-east England for the first time. The expected numbers based on people born in any part of the UK were 28.7 men and 48.5 women. In men alcoholic psychosis and alcoholism was the largest diagnostic category ( 28 admissions, 3.2 expected) followed by personality and behaviour disorders (12 admissions, 3.9 expected) and other psychoses (nine admissions, $2 \cdot 1$ expected). Four men were admitted for schizophrenia ( $3 \cdot 2$ expected). In women psychoneuroses was the large diagnostic category (12 admissions, $7 \cdot 7$ expected). Six women were admitted for alcoholic psychosis or alcoholism ( 1.6 expected) and five for schizophrenia ( 4.0 expected). First admissions for alcoholic psychosis and alcoholism when the sexes were combined were seven times the expected number ( 34 admissions, 4.8 expected) $(p<0.01)$. Seven people were admitted for alcoholic psychosis and 27 for alcoholism.

In the Republic of Ireland admissions for schizophrenia and, to a less extent, alcoholic psychosis and alcoholism are relatively more common among single people. ${ }^{3}$ In south-east England in 1976 a higher proportion of men admitted for schizophrenia were single than were married, widowed, divorced, or separated combined (table IV). There was little difference in the proportion of single people between those born in the UK and the Irish immigrants, but a higher proportion of those born in the UK were widowed, divorced, or separated. Although schizophrenia is more common among single 
TABLE IV-Rates of admission to psychiatric hospitals in south-east England in 1976 related to marital state (figures in parentheses are actual numbers of admissions)

\begin{tabular}{|c|c|c|c|c|c|c|c|c|}
\hline \multirow[b]{2}{*}{ Diagnosis } & \multicolumn{4}{|c|}{ Men } & \multicolumn{4}{|c|}{ Women } \\
\hline & Single & Married & $\begin{array}{c}\text { Widowed, } \\
\text { divorced, or separated }\end{array}$ & Total & Single & Married & $\begin{array}{c}\text { Widowed, } \\
\text { divorced, or separated }\end{array}$ & Total \\
\hline \multicolumn{9}{|c|}{ People born in United Kingdom } \\
\hline $\begin{array}{l}\text { Schizophrenia } \\
\text { Alcoholic psychosis and alcoholism } \\
\text { Psychoneuroses } \\
\text { All diagnoses }\end{array}$ & $\begin{array}{l}60 \cdot 9(343) \\
29 \cdot 1(165) \\
29 \cdot 7(201) \\
36 \cdot 1(1824)\end{array}$ & $\begin{array}{l}24 \cdot 7(139) \\
44 \cdot 4(252) \\
54 \cdot 1(366) \\
45 \cdot 5(2298)\end{array}$ & $\begin{array}{l}14 \cdot 4(81) \\
26 \cdot 5(150) \\
16 \cdot 1(109) \\
18 \cdot 4(934)\end{array}$ & $\begin{array}{r}(563) \\
(567) \\
(676) \\
(5056)\end{array}$ & $\begin{array}{l}35 \cdot 7(224) \\
18 \cdot 2(47) \\
18 \cdot 9(238) \\
24 \cdot 5(1836)\end{array}$ & $\begin{array}{l}34 \cdot 4(216) \\
45 \cdot 0(116) \\
57 \cdot 6(725) \\
44 \cdot 0(3295)\end{array}$ & $\begin{array}{l}29 \cdot 9(188) \\
36 \cdot 8(95) \\
23 \cdot 5(295) \\
31 \cdot 5(2354)\end{array}$ & $\begin{array}{r}(628) \\
(258) \\
(1258) \\
(7485)\end{array}$ \\
\hline \multicolumn{9}{|c|}{ Immigrants from Republic of Ireland and Ireland part not stated } \\
\hline $\begin{array}{l}\text { Schizophrenia } \\
\text { Alcoholic psychosis and alcoholism } \\
\text { Psychoneuroses } \\
\text { All diagnoses }\end{array}$ & $\begin{array}{l}52 \cdot 3(23) \\
31 \cdot 3(36) \\
44 \cdot 0(11) \\
38 \cdot 8(132)\end{array}$ & $\begin{array}{l}36 \cdot 4(16) \\
48 \cdot 7(56) \\
48 \cdot 0(12) \\
44 \cdot 1(150)\end{array}$ & $\begin{array}{l}11 \cdot 4(5) \\
20 \cdot 0(23) \\
80 \cdot 2(2) \\
17 \cdot 1(58)\end{array}$ & $\begin{array}{l}(44) \\
(115) \\
(25) \\
(340)\end{array}$ & $\begin{array}{l}44 \cdot 2(23) \\
22 \cdot 7(10) \\
16 \cdot 7(12) \\
24 \cdot 7(100)\end{array}$ & $\begin{array}{c}40 \cdot 4(21) \\
52 \cdot 3(23) \\
63 \cdot 9(46) \\
214(52 \cdot 8)\end{array}$ & $\begin{array}{l}15 \cdot 4(8) \\
25 \cdot 0(11) \\
19 \cdot 4(14) \\
22 \cdot 5(91)\end{array}$ & $\begin{array}{r}(52) \\
(44) \\
(72) \\
(405)\end{array}$ \\
\hline \multicolumn{9}{|c|}{ Migrants from Northern Ireland } \\
\hline $\begin{array}{l}\text { Alcoholic psychosis and alcoholism } \\
\text { All diagnoses }\end{array}$ & $\begin{array}{l}35 \cdot 7(10) \\
32 \cdot 4(23)\end{array}$ & $\begin{array}{l}42 \cdot 9(12) \\
43 \cdot 7(31)\end{array}$ & $\begin{array}{l}21 \cdot 4(6) \\
23 \cdot 9(17)\end{array}$ & $\begin{array}{l}(28) \\
(71)\end{array}$ & $\begin{array}{l}16 \cdot 7(1) \\
21 \cdot 7(15)\end{array}$ & $\begin{array}{l}33 \cdot 3(2) \\
53 \cdot 6(37)\end{array}$ & $\begin{array}{l}50 \cdot 0(3) \\
24 \cdot 6(17)\end{array}$ & $\begin{array}{r}(6) \\
(69)\end{array}$ \\
\hline \multicolumn{9}{|c|}{ New Commonwealth immigrants } \\
\hline $\begin{array}{l}\text { Schizophrenia } \\
\quad \text { All diagnoses }\end{array}$ & $\begin{array}{l}58 \cdot 2(89) \\
48 \cdot 3(195)\end{array}$ & $\begin{array}{l}35 \cdot 9(55) \\
41 \cdot 8(169)\end{array}$ & $\begin{array}{l}5 \cdot 9(9) \\
9 \cdot 9(40)\end{array}$ & $\begin{array}{l}(153) \\
(404)\end{array}$ & $\begin{array}{l}35 \cdot 0(42) \\
35 \cdot 5(162)\end{array}$ & $\begin{array}{l}50 \cdot 0(60) \\
50 \cdot 7(231)\end{array}$ & $\begin{array}{l}15 \cdot 0(18) \\
13 \cdot 8(63)\end{array}$ & $\begin{array}{l}(120) \\
(456)\end{array}$ \\
\hline
\end{tabular}

than married people, being single did not appear to account significantly for the higher than expected number of admissions for schizophrenia and alcoholic psychosis and alcoholism among the Irish immigrants compared with people born in the UK, nor for the higher than expected number of admissions for alcoholic psychosis and alcoholism among the migrants from Northern Ireland. Some married male immigrants may be leading single lives because their wives remain in Ireland.

\section{Discussion}

In this study we found that immigrants from Ireland and migrants from Northern Ireland living in south-east England had a significantly higher incidence of first admissions to psychiatric hospitals than would be expected, based on the age- and sex-standardised first admissions of people born in any part of the UK living in the region. This was not surprising, as immigrants of different nationalities in many countries have higher rates of admission to psychiatric hospitals than the native-born population. Many other studies, however, have not allowed for differences in age and sex structures between the native and immigrant populations.

Three main hypotheses have been put forward to explain the relation between migration and psychiatric morbidity. ${ }^{4}$ The country of origin of the migrant may have higher incidences of psychiatric illness than the host country. The process of migration may of itself lead to higher rates of illness in the migrants, or the forces that operate in the selection of the migrant population may be related to risk factors for mental illness.

The Irish immigrants in south-east England had admission rates that were intermediate between the high rates of those resident in Ireland and the lower rates of those born in England and Wales. Probably several factors combine to cause these differences. Walsh found that the differential between England and Wales and Ireland was reduced when the rate of admission to hospital was standardised, not just for age and sex but also for marital state and socioeconomic group, and similar standardisation might reduce the differences in rates between the population groups in the present study. ${ }^{5}$ Cochrane and StopesRoe suggested that the high rate of admissions to mental hospitals among Irish immigrants might be due to a small, separate group of "deteriorated immigrants" rather than to a high degree of psychopathology throughout the community. ${ }^{6}$

To assess further the extent to which higher rates of admission to psychiatric hospitals among the Irish in Ireland reflect greater psychiatric morbidity in the population, admission rates must be standardised for marital state, socioeconomic group, occupation, and perhaps other social factors. In addition, the degree of symptoms that cause a patient and his family to seek medical care may be lower in Ireland. The degree of illness leading to admission to psychiatric hospitals may also be lower, and the higher admission rates may reflect fewer community support services. Further studies of admission practices are necessary before an adequate explanation can be provided of the high first admission rates among the Irish in Ireland, the intermediate rates among Irish immigrants in England, and the low rates among the UK-born in England.

The high number of first admissions for alcoholic psychosis and alcoholism found among Irish immigrants and migrants from Northern Ireland resident in south-east England contrasts with the small number of admissions for alcoholism among New Commonwealth immigrants (G Dean et al, paper in preparation). Irish immigrants also have a high risk of first admissions to psychiatric hospital for schizophrenia. Birthplace is often omitted in the space provided on the Psychiatric In-Patient Identification Sheet and, in general hospitals, on the Hospital Activity Analysis forms. Because of the great difference in the pattern of disease between the various immigrant populations and the native-born population it is of the greatest importance that birthplace should be noted.

We thank the staff of the Department of Health and Social Security, Blackpool, for providing the data for this study and also the staff of the Office of Population Censuses and Surveys, London, for their help in determining the population structure of each immigrant group. The study was made possible by the co-operation of the records staff of the psychiatric hospitals, who made a special effort in 1976 to make sure that the place of residence was accurately recorded. We also thank Miss Jodie Walsh and Miss Hilda McLoughlin of the Medico-Social Research Board, Dublin.

This study was supported in its initial stages by the Schizophrenia Foundation, and we should like to thank Professor Miriam Lane and the trustees of the Foundation.

\section{References}

${ }^{1}$ Office of Population Censuses and Surveys. Reports of the counties of England and Wales. London: HMSO, 1976.

${ }^{2}$ O'Hare A, Walsh D. Activities of Irish psychiatric hospitals and units 1975 and 1976. Dublin: Medico-Social Research Board, 1978.

${ }^{3}$ Central Statistics Office. Census of population of Ireland 1979. Bulletin No 1. Dublin: Central Statistics Office, 1980.

${ }^{4}$ Murphy HBM. Migration and the major mental disorders; a reappraisal. In: Zwingmann $\mathrm{C}$, Pfister-Ammende $\mathrm{M}$, eds. Uprooting and after. New York: Springer, 1973.

${ }^{5}$ Walsh D. Patients in Irish psychiatric hospitals in 1963-a comparison with England and Wales. Br F Psychiatry 1971;118:617-20.

${ }^{6}$ Cochrane R, Stopes-Roe M. Psychological disturbance in Ireland, in England and in Irish emigrants to England: A comparative study. Economic and Social Review 1979;10:301.

(Accepted 10 April 1981) 